\title{
PELATIHAN TEKNOLOGI TEPAT GUNA PEMBUATAN SABUN CAIR PADA IBU-IBU PKK DI RW 9 DAN 17 DESA CIBIRU WETAN KECAMATAN CILEUNYI KABUPATEN BANDUNG
}

\author{
Elis Susilawati ${ }^{1)}$, Ika Kurnia Sukmawati ${ }^{2}$, R. Herni Kusriani ${ }^{3)}$, Widhya Aligita ${ }^{4)}$ \\ Sekolah Tinggi Farmasi Bandung \\ J1. Soekarno Hatta No. 754 Bandung \\ elis.susilawati@stfb.ac.id
}

\begin{abstract}
ABSTRAK
Dengan diadakannya pelatihan pembuatan sabun cair pada ibu-ibu PKK di RW Pengoptimalan kegiatan ibu-ibu PKK Di RW 9 dan 17 Desa Cibiru Wetan Kecamatan Cileunyi Kabupaten Bandung diharapkanakan dapat meningkatkan kreatifitas masyarakat guna menunjang perekononian keluarga, melalui pelatihan ini masyarakat lebih punya pengetahuan mengenai peluang usaha yang dapat tercipta melalui kreatifitas dan keterampilan dalam proses pembuatan sabun cair. Pelatihan teknologi tepat guna pembuatan sabun cair dilaksanakan melalui beberapa tahap yaitu dengan koordinasi dengan mitra terkait dengan penyusunan jadwal kegiatan, persiapan penyuluhan dan pelatihan. Penyuluhan tentang prinsip dasar pembuatan sabun cair lalu dan pelatihan cara pembuatan sabun cair. Hasil pelatihan pembuatan sabun cair ini dikemas dan di gunakan untuk keluarga nya masing-masing, diharapkan dapat dikembangkan menjadi turut memenuhi kebutuhan keluarganya sehingga dengan melakukan sendiri akan menghemat keuangan keluarga dan dapat dijadikan bekal untuk membuka usaha yang pada akhirnya dapat menambah penghasilan keluarga.
\end{abstract}

Kata Kunci : Teknoogi tepat guna, sabun cair

\begin{abstract}
With the holding of training making liquid soap on mothers PKK in RW Optimisation activities moms PKK In RW 9 and 17 Village Cibiru Bandung Regency Cileunyi Subdistrict Wetan diharapkanakan can increase the creativity of the community to support perekononian family, through this training more community had knowledge about the business opportunities that can be created through the creativity and skill in the process of making liquid soap. Training of appropriate technology of making liquid soap is implemented through several stages with coordination with the partners associated with the preparation of a schedule of activities, the preparation of outreach and training. Extension of the basic principle of making liquid soap and liquid soap preparation training. The results of the training of making liquid soap is packaged and in use for his family each, are expected to be developed into hardness, meets the needs of the family so that by doing it yourself will save a family finance and can be provision was made to open a business which in the end can add to family income.
\end{abstract}

Keywords: appropriate Teknoogi, liquid soap. 


\section{PENDAHULUAN}

Keberdayaan perempuan di bidang ekonomi adalah salah satu indikator meningkatnya kesejahteraan. Saat perempuan menjadi kaum terdidik, mempunyai hak-hak kepemilikan, dan bebas untuk bekerja di luar rumah serta mempunyai pendapatan mandiri, inilah tanda kesejahteraan rumah tangga meningkat. Lebih dari itu, perempuan juga mempunyai andil besar dalam kegiatan penanggulangan kemiskinan melalui pemberdayaan masyarakat dan kelompok. Salah satu buktinya, bahwa perempuan dapat meningkatkan kesejahteraan keluarganya dengan melakukan kegiatan usaha produktif rumah tangga.

Pemberdayaan Ibu-ibu PKK sebagai anggota masyarakat dan masih tergolong sebagai tenaga kerja produktif sangat penting dilakukan, bertujuan untuk menumbuhkan kesadaran dan kemandirian dalam berusaha, sekaligus memperluas lapangan kerja guna meningkatkan pendapatan keluarga dalam usaha mencapai keluarga yang bahagia dan sejahtera. Dalam kaitannya dengan upaya untuk membina dan mengembangkan potensi keluarga dan daerah, dapat dilakukan melalui berbagai alternatif kegiatan, diantaranya berupa pelatihan pembuatan sabun cair. Sabun merupakan sebuah komoditas yang tidak bisa dilepaskan dari kebutuhan rumah tangga dewasa ini. Alat produksi yang digunakan dalam proses pembuatannya tidaklah banyak dan rumit layaknya pabrik-pabrik besar.

Alternatif ini dipilih mengingat ibu-ibu kader PKK di wilayah ini membutuhkan pengetahuan dan keterampilan yang dapat dijadikan bekal untuk merintis usaha dan mereka sebelumnya belum pernah mendapatkan latihan keterampilan ini. Peluang pemasarannya sangat terbuka lebar disamping itu kegiatan yang ditawarkan ini dapat dikerjakan dirumah sehingga ibu-ibu akan lebih mudah menyesuaikan dengan peran domestiknya sebagai ibu rumah tangga.

\section{TARGET DAN LUARAN}

\subsection{Luaran}

Target yang diharapkan dalam Program Pengabdian Masyarakat berbasis Ipteks bagi Masyarakat ini adalah :

a. Pendampingan dan bimbingan kelompok mitra dalam pelatihan pembuatan sabun mandi cair.

b. Memberikan keterampilan dan pengetahuan yang baru kepada masyarakat tentang cara pembuatan sabun mandi cair dan cara mendapatkan bahanbahannya.

c. Barang berupa Produk Sabun cair, dengan adanya hasil contoh produk sabun cair, diharapkan kelompok mitra ibu-ibu PKK tersebut memiliki gambaran inovatif bagaimana cara membuat sabun cair yang bisa dijadikan sumber ekonomi kelompok atau perorangan.

\subsection{Luaran}

Luaran yang akan dicapai dalam Program Pengabdian Masyarakat berupa:

1. Publikasi ilmiah pada jurnal nasional.

2. Laporan Pengabdian 


\section{METODE PELAKSANAAN}

Metode pelaksanaan kegiatan pengabdian kepada masyarakat yang akan dilakukan adalah sebagai berikut

a. Koordinasi dengan mitra, terkait dengan penyusunan jadwal kegiatan

b. Penyuluhan.

Materi penyuluhan memaparkan tentang prinsip dasar pembuatan, cara mendapatkan bahan-bahan yang digunakan dan teknik pengemasan

c. Pelatihan

Pada waktu sesi pelatihan mitra secara langsung diberikan contoh terlabih dahulu dalam proses pembuatan sabun cair tersebut dan selanjutnya mitra di minta untuk mempraktekan sendiri.

\section{HASIL DAN PEMBAHASAN}

Kegiatan pengabdian ini dilakukan di Perumahan Cibiru Asri RW 17 dan juga melibatkan ibu-ibu PKK RW 9 Desa Cibiru Wetan Kecamatan Cileunyi Kabupaten Bandung, kegiatan yang dilakukan adalah sebagai berikut :

\section{Koordinasi dengan pihak-pihak terkait.}

Koordinasi tim pengabdian masyarakat dari Sekolah Tinggi Farmasi Bandung dengan mitra yaitu RW 17 dan juga ibu-ibu PKK yang berada di RW 17 dan RW 9. Pada kegiatan ini tim pengabdian dan mitra membahas tentang kegiatan yang akan dilaksanakan, tempat dan waktu pelaksanaan penyuluhan dan pelatihan. Pada pertemuan ini ada beberapa hal yang disepakati, yaitu kegiatan sosialisasi kegiatan, waktu dan tempat pelaksanaan penyuluhan dan pelatihan pembuatan sabun mandi cair.

\section{Persiapan Penyuluhan dan Pelatihan}

Persiapan kegiatan ini dimulai dari penentuan formula sabun mandi cair dan pembuatan materi dalam bentuk power point yang berisi tema, tujuan, target dan luaran dari penyuluhan dan pelatihan pembuatan sabun mandi cair tersebut. Kemudian dilakukan perbanyakan materi untuk dibagikan kepada mitra. Pada persiapan pelatihan, Tim pengabdian melakukan uji coba formula pembuatan produk sabun mandi cair, sehingga didapatkan komposisi yang tepat dan memberikan hasil optimal.

Pelaksanaan Penyuluhan

Penyuluhan dilakukan di halaman Mesjid Nurul Asri RW 17 dengan pertimbangan tempatnya luas juga berada di tengah-tengan Komplek Cibiru Asri dan dari RW 9 juga mudah terjangkau, karena RW 9 berada diluar Komplek Cibiru Asri.

Penyuluhan dalam bentuk ceramah yang menjelaskan materi tentang metode dan cara pembuatan sabun mandi cair dan penjelasan bahan-bahan yang digunakan dalam kegiatan tersebut, adapun bahanbahan yang digunakan adalah : Comperland + CAB , texapon, EDTA $4 \mathrm{Na}$, nipagin, gliserin, $\mathrm{NaCl}$, Acid citric pewarna, parfum dan air. Penjelasan tentang materi dapat dilihat pada Gambar 1.

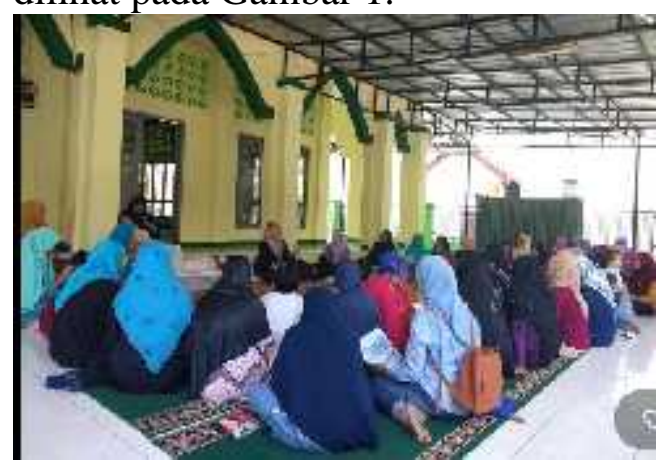

Gambar 1. Penjelasan materi cara pembuatan sabun mandi cair. 
Kemudian setalah semua paham dan tidak ada yang bertanya lagi, dengan dibimbing tim pengabdian mempraktekkan sendiri pembuatan produk tersebut. Pelatihan dilaksanakan sampai semua peserta mahir. Tahapan atau proses pembuatan sabun mandi ini adalah dimulai dari pencampuran bahanbahan sebagai berikut : Pertama campurkan comperland dan $\mathrm{CAB}$ kemuadian kocok sampai kental, lalu tambahkan texapon aduk rata, kemudian tambahkan air sebanyak 50 $\mathrm{mL}$ aduk lagi sampai rata, lalu tambahkan EDTA $4 \mathrm{Na}$, nipagin, air $200 \mathrm{~mL}$ kemudian diaduk lagi sampai rata. Tambahkan gliserin aduk rata, tambahkan $\mathrm{NaCl}$, air $50 \mathrm{~mL}$ aduk rata, tambahkan acid citric dan air 30 mL aduk rata

Dan terakhir tambahkan pewarna lalu parfum dan air sisa sebanyak $80 \mathrm{~mL}$ aduk rata sampai benar-benar homogen lalu simpan dalam wadah tertutup selama seharian biar didapatkan sabun mandi cair yang benar-benar baik. Proses pembuatan dapat dilihat pada gambar 2 .
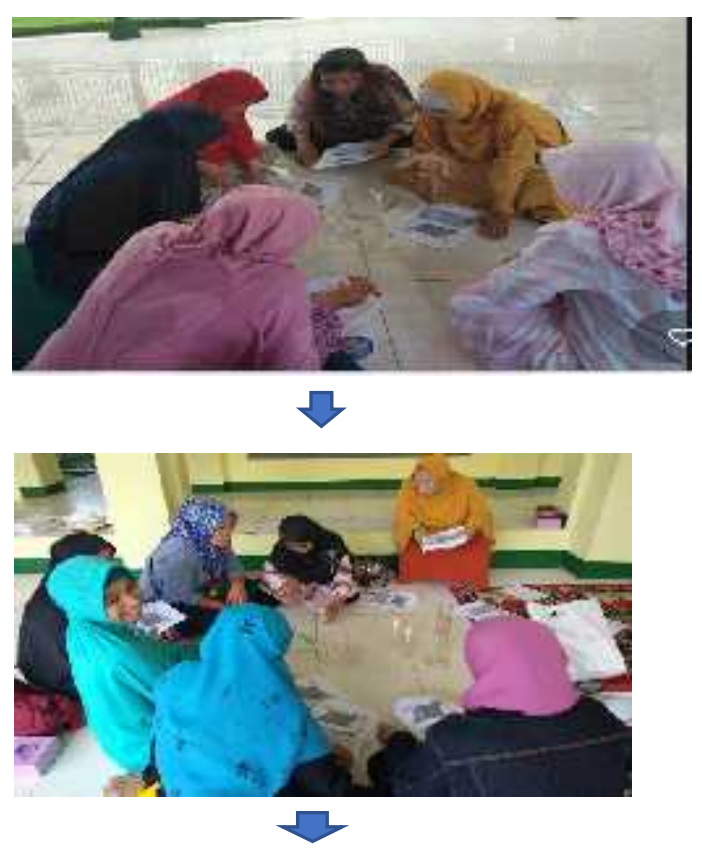
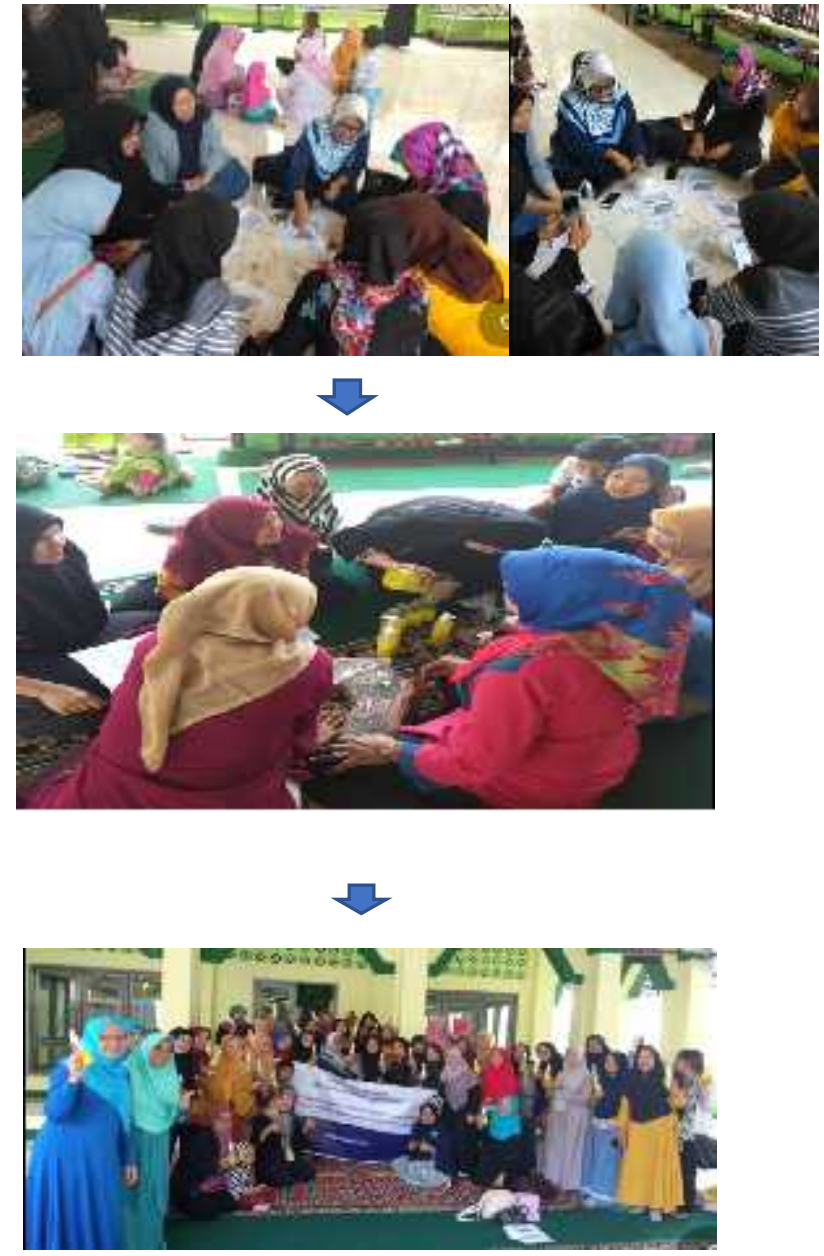

Gambar 2. Proses pembuatan sabun mandi cair bersama mitra.

Pelatihan teknologi tepat guna pembuatan sabun cair pada ibu-ibu PKK di RW 9 dan 17 Desa Cibiru Wetan Kecamatan Cileunyi Kabupaten Bandung ini telah di publikasikan media cetak yang dapat dilihat pada Gambar 3.

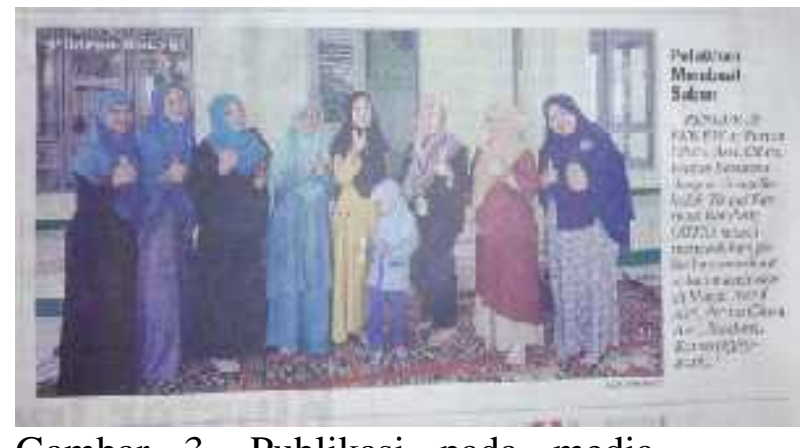

Gambar 3. Publikasi pada media cetak 


\section{Evaluasi dan Tindak Lanjut \\ Evaluasi dan tindak lanjut terus dilakukan dengan cara terus melakukan komunikasi dengan mitra, dan ada beberapa mita yang mulai bertanya bagaimana cara-cara pendapatkan bahan-bahan dan peralatan yang digunakan untuk pembuatan sabun mandi cair ini secara detail.}

\section{KESIMPULAN}

Berdasarkan hasil pelaksanaan kegiatan pengabdian, dapat disimpulkan sebagai berikut:

a. Kegiatan pengabdian masyarakat terlaksana sesuai dengan yang sudah direncana.

b. Kegiatan pengabdian dari koordinasi, penyuluhan dan pelatihan mendapatkan sambutan yang baik dari Mitra yaitu RW 9 dan RW 17

c. Beberapa ibu-ibu PKK yang berada di RW 6 dan RW 17 mendapatkan keterampilan tambahan tentang pembuatan sabun mandi cair.

\section{UCAPAN TERIMA KASIH}

Kami ucapkan banyak terima kasih kepada Sekolah Tinggi Farmasi Bandung, P3M, Tim Pengabdian Masyarakat (Dosen-dosen yang terlibat) dan Ibu-ibu Warga RW 9 dan 17 Desa Cibiru Wetan Kecamatan Cileunyi Kabupaten Bandung.

\section{DAFTAR PUSTAKA}

Badan Standarisasi Nasional., 1994. Standar Mutu Sabun Mandi. SNI 06-3532-1994. Dewan Standardisasi Nasional. Jakarta.

Boesro Soebagio, Sriwidodo, Irni Anggraini, Formulasi Sabun Mandi Cair Dengan Lendir Daun Lidah Buaya, Jurusan Farmasi FMIPA UNPAD, Jatinangor-Sumedang.

Rohmah Jamilatur dkk. 2017. PPMTKP Ibu-Ibu PKK Desa Keboharan Kecamatan Krian Kabupaten Sidoarjo Provinsi Jawa Timur. Universitas Muhammadiyah Sidoarjo.

Susanti Elfi VH , Endang Susilowati. 2016. Pemberdayaan Ibu-Ibu PKK Melalui Pelatihan Dan Pendampingan Produksi Sabun Dan Deterjen. Vol. IV No.2 Nopember 2016. FKIP, Universtas Sebelas Maret

Susanti Elfi VH, Endang Susilowati. 2016. Pemberdayaan Ibu-Ibu Pkk Melalui Pelatihan dan Pendampingan Produksi Sabun dan Deterjen. FKIP, Universtas Sebelas Maret.

https://nivitasya.wordpress.com/rese p-kimia/ (Diakses 16 September 2018) 